(C) The Author(s), 2021. Published by Cambridge University Press on behalf of the British Institute at Ankara. This is an Open Access article, distributed under the terms of the Creative Commons Attribution licence (http://creativecommons.org/licenses/by/4.0/), which permits unrestricted reuse, distribution and reproduction in any medium, provided the original work is properly cited.

\title{
The recent contribution of scientific techniques to the study of Nokalakevi in Samegrelo, Georgia
}

\author{
Paul Everill, ${ }^{1}$ Nikoloz Murgulia, ${ }^{2}$ Davit Lomitashvili, ${ }^{3}$ Ian Colvin, ${ }^{4}$ \\ Besik Lortkipanidze, ${ }^{2}$ Jean-Luc Schwenninger ${ }^{5}$ and Gordon Cook ${ }^{6}$ \\ ${ }^{1}$ University of Winchester, UK, ${ }^{2}$ Georgian National Museum, Georgia, ${ }^{3}$ National Agency for \\ Cultural Heritage Preservation of Georgia, Georgia, ${ }^{4}$ University of Cambridge, UK, \\ ${ }^{5}$ University of Oxford, $U K$, and ${ }^{6}$ University of Glasgow, $U K$ \\ Paul.Everill@winchester.ac.uk
}

\begin{abstract}
The site of Nokalakevi, in western Georgia, has seen significant excavation since 1973, including, since 2001, a collaborative Anglo-Georgian project. However, the interpretation of the site has largely rested on architectural analysis of standing remains and the relative dating of deposits based on the study of ceramics. Since 2013, the AngloGeorgian Expedition to Nokalakevi has collected a diverse dataset derived from multiple scientific techniques including optically stimulated luminescence (OSL) dating of ceramics, radiocarbon dating, $\delta^{13} \mathrm{C}$ and $\delta^{15} \mathrm{~N}$ analysis and ${ }^{87} \mathrm{Sr} r{ }^{86} \mathrm{Sr}$ analysis. The full results of these analyses are reported here for the first time along with implications for the interpretation of the archaeology, which include greater detail in the site chronology but also indicators of diet and migration.
\end{abstract}

\section{Özet}

Batı Gürcistan'daki Nokalakevi yerleşim yerinde, 2001'de başlamış olan bir İngiliz-Gürcü ortak projesi de dahil olmak üzere, 1973 'ten beri önemli kazılar yapılmıştır. Bununla birlikte, yerleşimin yorumlanması büyük ölçüde ayakta kalmış olan kalıntıların mimari analizine ve seramik çalışmalarına dayanarak yapılmış olan, tabakaların göreceli tarihlendirmesine dayanmaktadır. Nokalakevi'de yapılan İngiliz-Gürcü ortak kazıları 2013'ten bu yana seramikleri, optik uyarmalı lüminesans (OSL) tarihlemesi, radyokarbon tarihlemesi, $\delta^{13} \mathrm{C}$ ve $\delta^{15} \mathrm{~N}$ analizi ve ${ }^{87} \mathrm{Sr}{ }^{86} \mathrm{Sr}$ analizleri dahil olmak üzere birçok bilimsel teknikten yararlanarak incelemiş ve çeşitli verilere ulaşmıştır. Bu analizlerin tam sonuçları, arkeolojinin yorumlanmasına yönelik çıkarımlarla birlikte ilk kez burada rapor edilmektedir. Bu rapor, yerleşimin kronolojisiyle ilgili daha fazla ayrıntıya ve aynı zamanda beslenme ve göç göstergelerini de içeren bazı çıkarımlara sahiptir.

$\mathrm{T}$ he ruins in the small village of Nokalakevi in Samegrelo, western Georgia (fig. 1), have attracted scholarly interest since the first half of the 19th century (Dubois de Montpéreux 1839; Everill 2019). They were first excavated in 1930 (Schneider 1931), confirming their identification with the remains of the fortress of Archaeopolis described in early Byzantine historical sources, also known as Tsikhegoji (the fortress of Kuji) or 'the triple-walled fortress' by the Georgian chroniclers. The fortifications, on the northern edge of the Colchian plain, enclose a naturally defensible area of approximately 18ha, with a steep limestone gorge carved by the river Tekhuri to the north, west and (to a lesser extent) south. A

hilltop citadel stands more than $200 \mathrm{~m}$ above the lower town - a strip of relatively level ground between the hill and the river on which most of the known buildings were situated (fig. 2).

The site has seen human activity since at least the eighth century $\mathrm{BC}$, though the surviving walls date to between the fourth and sixth centuries AD. Archaeological excavations (by the Simon Janashia State Museum of Georgia beginning in 1973 [Zakaraia 1981; 1987; 1993] and as the collaborative Anglo-Georgian Expedition since 2001 [Everill 2014]) have produced a large number of fragments of double-headed zoomorphic figurines that are only known from Nokalakevi and the site of Vani, on the 


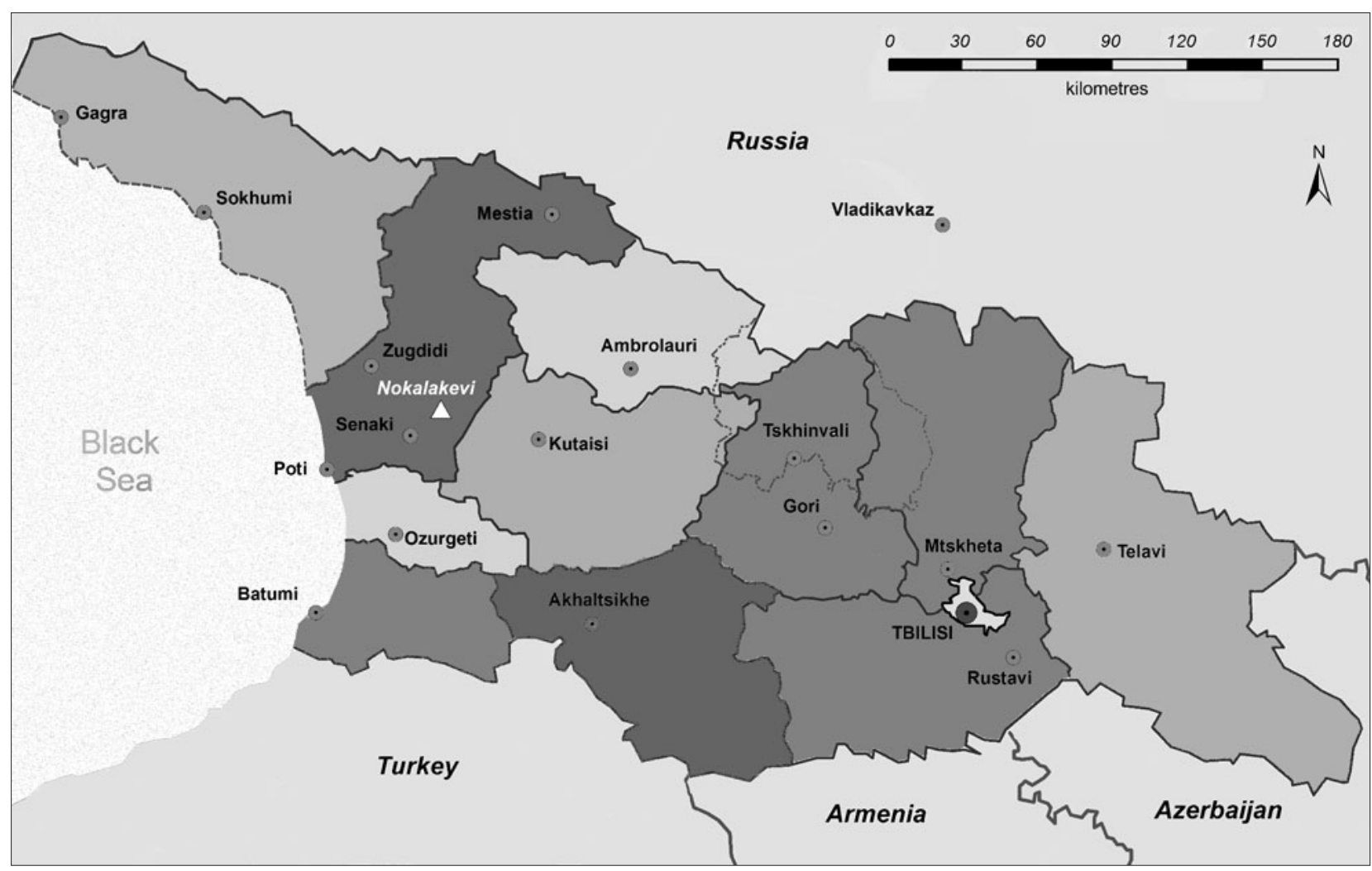

Fig. 1. Location of Nokalakevi, about 50km east of the Black Sea coast, in Samegrelo.

southern edge of the Colchian plain. These figurines were apparently deliberately broken, perhaps sacrificed, in the Iron Age in an area of the site that evidence suggests may have experienced periods of boggy conditions. While no contemporary settlement or burials have yet been found, the climatic conditions had clearly improved considerably by the sixth/fifth century $\mathrm{BC}$, for which the evidence for occupation is far more substantial and expands through the Hellenistic period. Burials from the latter period seem to respect existing wall lines, and it is considered possible that the focus of the settlement moved at this time, with the lower town becoming a necropolis and burials being located along the wall stubs of the earlier buildings. The settlement in Nokalakevi - founded, according to legend, by the western Georgian ruler Kuji in the Hellenistic period - was clearly significant at this time. The modern name of the village, Nokalakevi, translates as 'ruins where a town was', and, while this might refer to the Byzantine ruins, it is perhaps not coincidental that it was known as Archaeopolis ('ancient city') to those who built even those.

No evidence for settlement during the first three centuries $\mathrm{AD}$ - the period after the Mithridatic Wars in which the Kingdom of Colchis itself collapsed and western Georgia fell into the Roman sphere of influence - has been observed, but by the fourth century AD Nokalakevi was the centre of an expanding kingdom, Lazika (also known as Egrisi), which exercised hegemony over the other western Georgian tribes. Both the East Romans and the Persians sought the allegiance of the Laz, partly to stop the other expanding further and partly for the protection it offered against incursions by the nomadic peoples to the north of the Caucasus mountains. Competition between Byzantium and Persia led to a near permanent state of war, including the Great War of Egrisi (AD 541-562), during which Archaeopolis was attacked unsuccessfully several times by Persian forces. Excavations in the area of the lower town have revealed substantial stone buildings of the fourth to sixth century AD, including the extant Forty Martyrs' Church - built in the sixth century - and two earlier churches immediately to its south, visible today only as foundations exposed by the archaeological investigation. Immediately south of these foundations lie the ruins of a large stone-built building, interpreted as a palace, that was constructed around the beginning of the sixth century $\mathrm{AD}$ and converted into a wine-cellar in the 16th to 17 th century. A small vaulted, stone gatehouse, or belltower, lies approximately $25 \mathrm{~m}$ east of, and centred on, the first church. The surviving walls along which it is located suggest that it was constructed as the entrance to the earliest ecclesiastical precinct. Other stone structures revealed over many years of work in the lower town include: the remains of baths along the inside of the southern fortifications; a tunnel down to the river at the 


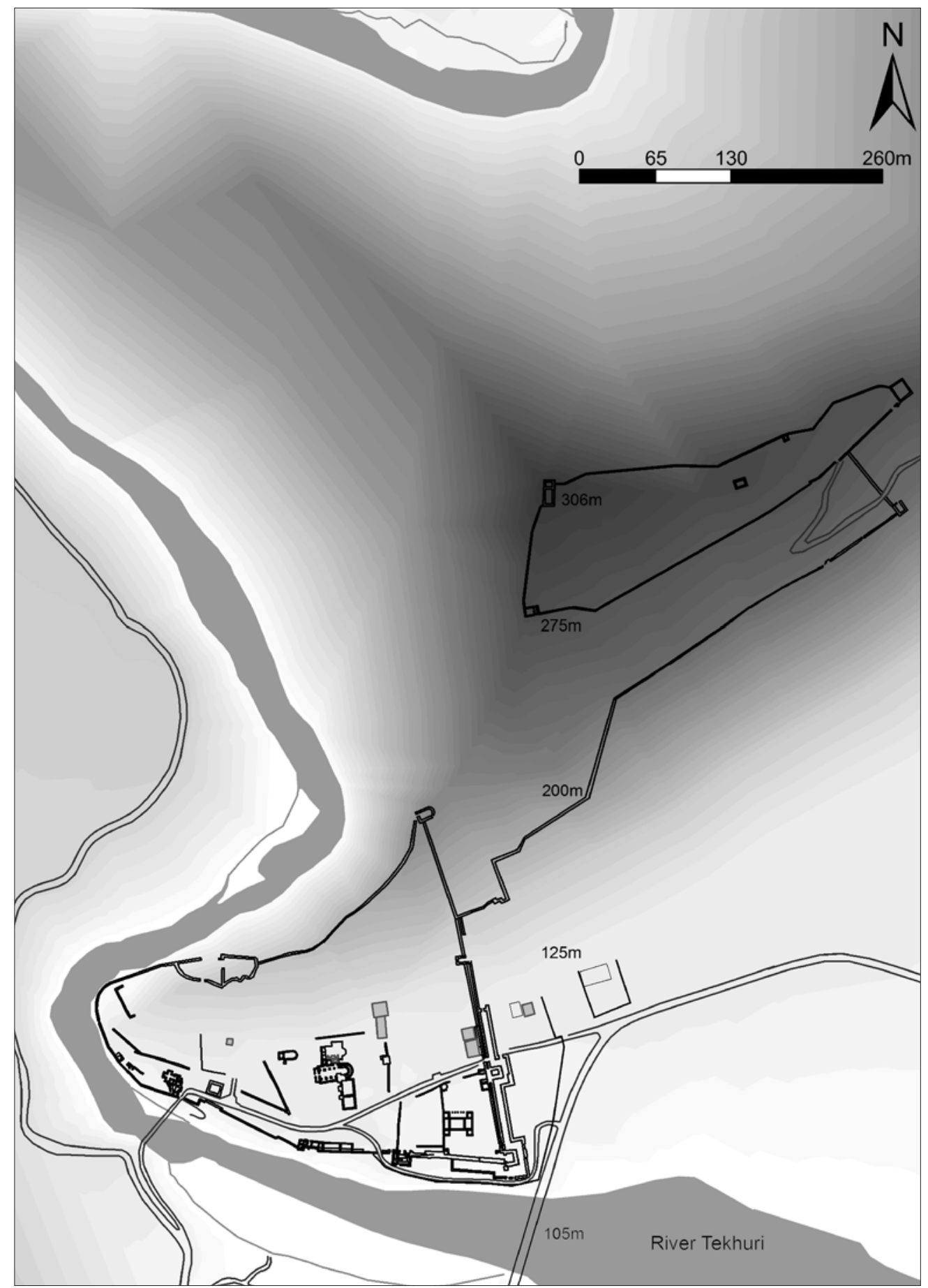

Fig. 2. Site plan of Nokalakevi, showing the lower town and citadel enclosed by the fourth-to sixth-century AD fortifications.

southwest of the site; a bathhouse $35 \mathrm{~m}$ east of the tunnel, apparently supplied by a cistern constructed up the slope, $50 \mathrm{~m}$ to its northwest; and a substantial rectangular building near the southeast of the area, which possibly housed the military commanders of the Byzantine and Laz garrison of the sixth century.

Excavations have also shed more light on the fortification works. These include the protruding towers of the first wall, dated to the fourth century $\mathrm{AD}$, that were made flush in the construction of the second phase in the fifth century. In the sixth century, re-modelling included moving the gate and changing the approach to it, so as to prevent a frontal attack. Excavations in the upper town, or citadel, have revealed multi-phase towers at the northwest and northeast of the fortifications, and another small gate and probable guardhouse in the southwestern corner. 


\section{The application of scientific techniques}

Since 2001 the excavation and recording methodology used for the trenches (fig. 3) has followed a modern stratigraphic approach, using a system derived from developerfunded professional archaeology in the UK that is capable of coping with $3.5 \mathrm{~m}$ of complex stratified sequences; this has also allowed for the training of Georgian and international students in up-to-date techniques. Dating of contexts has been achieved largely through the relative application of established Georgian ceramic chronologies. However, the Anglo-Georgian Expedition has been able to apply scientific techniques to a range of research questions since 2007, particularly from 2013, and has now built a diverse dataset derived from a range of techniques that is perhaps unparalleled in the region. These consist of optically stimulated luminescence (OSL) dating of ceramics, radiocarbon dating, $\delta^{13} \mathrm{C}$ and $\delta^{15} \mathrm{~N}$ analyses, and ${ }^{87} \mathrm{Sr} /{ }^{86} \mathrm{Sr}$ analysis. The OSL dating was undertaken at the Research Laboratory for Archaeology and the History of Art (RLAHA) at the University of Oxford, the ${ }^{14} \mathrm{C}$ analysis at Peking University (laboratory codes beginning BA) and the Scottish Universities Environmental Research Centre (SUERC) at the University of Glasgow, and the $\delta^{13} \mathrm{C}$ and $\delta^{15} \mathrm{~N}$ and ${ }^{87} \mathrm{Sr} /{ }^{86} \mathrm{Sr}$ analyses also at SUERC. While the exca- vations are ongoing, and this dataset will continue to grow, the results already obtained are contributing enormously to the understanding of the site and demonstrate the potential for their application more widely in the southern Caucasus.

Since 2013, 14 ceramic samples have been submitted for OSL dating (tables 1 and 2). The initial motivation was to get an indication of dates for the earliest archaeological deposits, within which no organic material was present; however, the programme was expanded to test the existing ceramic chronologies and to examine the extent of mixing within colluvial material. More commonly used in the dating of buried sediments, OSL results are based on the measurement of trapped charge released from mineral grains when external stimulus, in the form of light, is applied to sand-sized quartz $(60-255 \mu \mathrm{m})$ extracted from the inside of the sherds (Aitken 1998). Analysis of the results provides a date when the pot was fired, at which point the 'traps' were zeroed by the application of heat. Following this event, the mineral grains gradually gained charge through exposure to the radiation flux from naturally occurring radionuclides within the clay matrix and the surrounding sediment. In the absence of organic material, the technique provides a useful alternative to

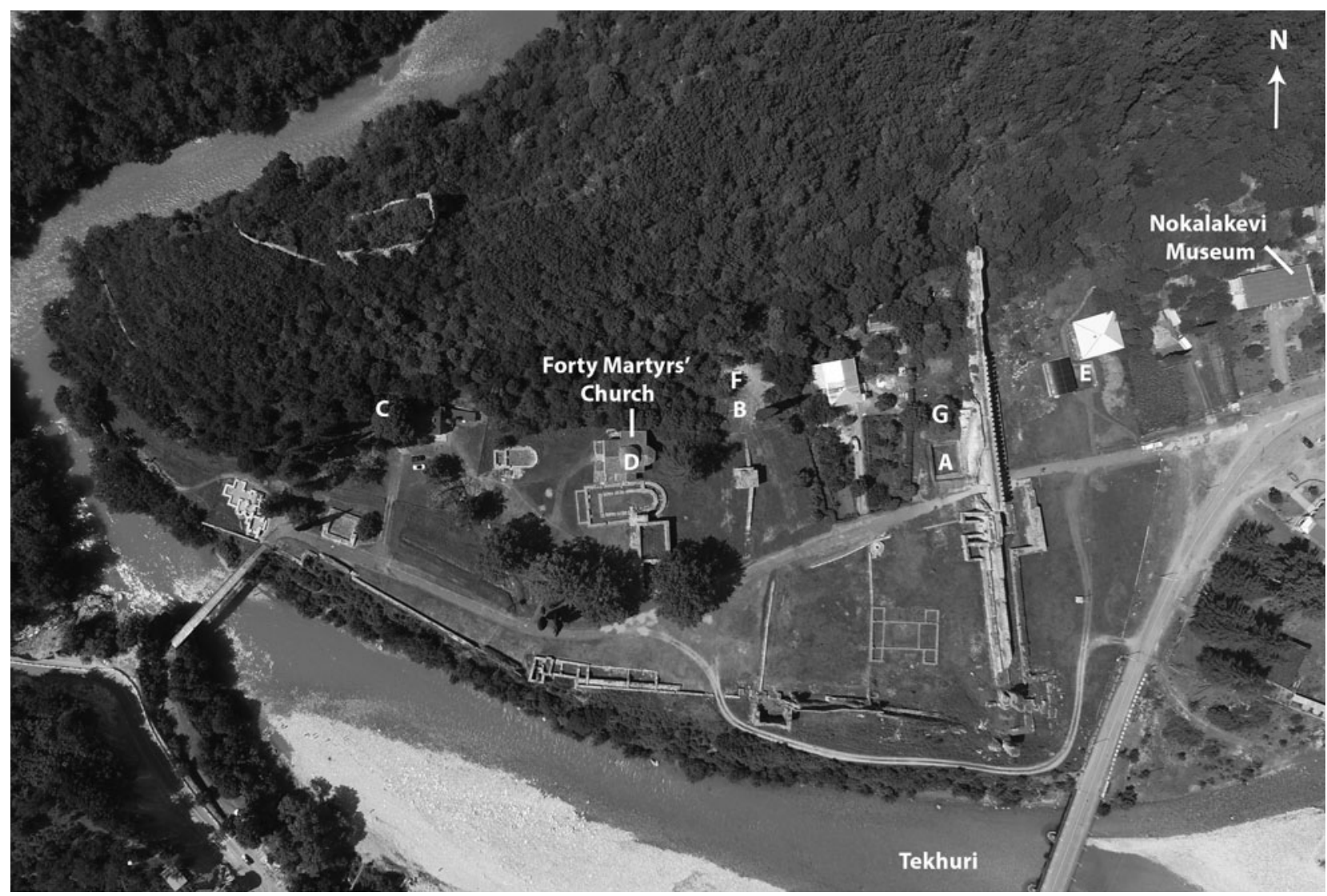

Fig. 3. Aerial view of the lower town at Nokalakevi, showing the positions of the trenches (A to $G$ ) excavated by the Anglo-Georgian Expedition since 2001 (C) National Agency for Cultural Heritage Preservation of Georgia, 2016). 


\begin{tabular}{|c|c|c|c|c|c|}
\hline Field code & $\begin{array}{l}\text { Laboratory } \\
\text { code }\end{array}$ & $\begin{array}{l}\text { Palaeodose } \\
\text { (Gy) }\end{array}$ & $\begin{array}{l}\text { External gamma- } \\
\text { dose rate }(G y / k a)\end{array}$ & $\begin{array}{l}\text { Total dose rate } \\
\qquad(\mathrm{Gy} / \mathrm{ka})\end{array}$ & $\begin{array}{l}\text { OSL age estimate (years } \\
\left.\text { before } 2015^{*} \text { or } 2016^{* *}\right)\end{array}$ \\
\hline NOK13/B Sample 4 & X5494 & $16.64 \pm 1.00$ & $1.07 \pm 0.11$ & $2.75 \pm 0.15$ & $\begin{array}{c}6055^{*} \pm 485 \\
(4525-3555 \mathrm{BC})\end{array}$ \\
\hline NOK13/B Sample 5 & X5495 & $12.11 \pm 0.88$ & $1.03 \pm 0.10$ & $2.65 \pm 0.15$ & $\begin{array}{c}4565^{*} \pm 420 \\
(2970-2130 \mathrm{BC})\end{array}$ \\
\hline NOK13/B Sample 8 & X5496 & $10.70 \pm 0.80$ & $0.93 \pm 0.09$ & $2.37 \pm 0.13$ & $\begin{array}{c}4505^{*} \pm 415 \\
(2905-2075 \mathrm{BC})\end{array}$ \\
\hline NOK15/C-3 (129) & X6912 & $15.5 \pm 1.59$ & $0.68 \pm 0.06$ & $2.40 \pm 0.12$ & $\begin{array}{c}6450 * * \pm 740 \\
(5174-3694 \mathrm{BC})\end{array}$ \\
\hline NOK15/A-1 (319) & X6913 & $5.66 \pm 0.31$ & $0.90 \pm 0.11$ & $2.48 \pm 0.15$ & $\begin{array}{c}6120 * * \pm 670 \\
(4774-3434 \mathrm{BC})\end{array}$ \\
\hline
\end{tabular}

Table 1. Dates for the earliest archaeological layers obtained by OSL on ceramic samples from three different trenches at Nokalakevi.

\begin{tabular}{|c|c|c|c|c|c|}
\hline Field code & $\begin{array}{l}\text { Laboratory } \\
\text { code }\end{array}$ & $\begin{array}{l}\text { Palaeodose } \\
(G y)\end{array}$ & $\begin{array}{l}\text { External gamma- } \\
\text { dose rate }(G y / k a)\end{array}$ & $\begin{array}{l}\text { Total dose rate } \\
\qquad(G y / k a)\end{array}$ & $\begin{array}{l}\text { OSL age estimate (years } \\
\left.\text { before } 2015^{*} \text { or } 2016^{* *}\right)\end{array}$ \\
\hline NOK14/A-2 (316) & X6678 & $5.66 \pm 0.31$ & $0.76 \pm 0.06$ & $2.16 \pm 0.11$ & $\begin{array}{l}2620 * \pm 190 \\
(795-415 \mathrm{BC})\end{array}$ \\
\hline NOK14/C-3 (113) & X6680 & $4.69 \pm 0.39$ & $0.73 \pm 0.05$ & $2.29 \pm 0.11$ & $\begin{array}{c}2050 * \pm 190 \\
(225 \mathrm{BC}-\mathrm{AD} 155)\end{array}$ \\
\hline NOK14/C-4 (113) & X6681 & $1.96 \pm 0.27$ & $0.73 \pm 0.05$ & $1.73 \pm 0.08$ & $\begin{array}{c}1130 * \pm 160 \\
(\mathrm{AD} 725-1045)\end{array}$ \\
\hline NOK14/C-5 (113) & X6682 & $2.24 \pm 0.19$ & $0.80 \pm 0.05$ & $2.56 \pm 0.12$ & $\begin{array}{c}870 * \pm 120 \\
(\mathrm{AD} 1025-1265)\end{array}$ \\
\hline NOK15/C-1 (114) & X6910 & $3.65 \pm 1.09$ & $0.71 \pm 0.06$ & $2.39 \pm 0.13$ & $\begin{array}{l}1530 * * \pm 470 \\
(\mathrm{AD} 16-956)\end{array}$ \\
\hline NOK15/C-2 (122) & X6911 & $3.97 \pm 0.32$ & $0.77 \pm 0.07$ & $2.40 \pm 0.12$ & $\begin{array}{l}1650^{* *} \pm 160 \\
(\mathrm{AD} 206-526)\end{array}$ \\
\hline $\begin{array}{l}\text { KHU15 Test pit } 3 \\
(302)\end{array}$ & X6914 & $3.57 \pm 0.38$ & $0.84 \pm 0.07$ & $2.61 \pm 0.13$ & $\begin{array}{l}1370^{* *} \pm 160 \\
(\mathrm{AD} 485-805)\end{array}$ \\
\hline $\begin{array}{l}\text { KHU15 Test pit } 2 \\
(202)\end{array}$ & X6915 & $8.48 \pm 1.58$ & $0.87 \pm 0.07$ & $3.08 \pm 0.16$ & $\begin{array}{c}2750 * * \pm 530 \\
(1264-204 \mathrm{BC})\end{array}$ \\
\hline
\end{tabular}

Table 2. OSL dates obtained from a zoomorphic figurine from Nokalakevi, ceramic samples from colluvial deposits in Trench C at Nokalakevi and ceramic samples from the contemporary site of Khuntsi.

radiocarbon dating, though the margin of error can be substantial due to the many uncertainties associated with the calculation of the dose rate. While 13 of the samples provided good OSL signal characteristics, one contained so few quartz crystals that the result was not considered reliable by the laboratory and so it is not discussed here.
The archaeological evidence has supported the hypothesis of initial human activity at Nokalakevi in the eighth century BC for at least two decades. However, in 2012, during the excavation of the earliest archaeological layers in the south of Trench B, new evidence was retrieved from stratified contexts. Flat, river-smoothed cobbles were 
found with notches made in their opposing sides (similar to the prehistoric fishing weights excavated in Adjara, southwestern Georgia, and now on display in Batumi Archaeological Museum). While it might be problematic to date this crude technology in isolation, the cobbles were found associated with the broken butt end of a roughly polished stone tool with a hole made for a shaft. The pottery sherds recovered from this deposit were also markedly different, appearing less sophisticated than those previously found at the site. In 2013, with the north of Trench B approaching completion, eight samples of pottery were collected and placed, unwashed, in a small bag containing surrounding soil for moisture analysis. Of the initial eight samples, three were selected for laboratory analysis on the basis that they were the most representative examples of the fabric types found. Two further samples were also analysed in 2015, from Trench A and Trench C, as excavation there also reached the earliest archaeological layers and produced similar pottery - though no further stone tools. The five results (table 1), despite a wide margin of error, appear to indicate two distinct phases of activity: the first somewhere within the range from the mid-fifth millennium BC (when a hypothesised major Black Sea regression, the Eggrisian, would have had a significant impact on human activity in western Georgia: Yanko-Hombach 2007; Martin, Yanko-Hombach 2011) to the mid-fourth millennium $\mathrm{BC}$ (Chalcolithic); and the second within the third millennium BC (Early/Middle Bronze Age). Clearly, it is not possible to draw firm conclusions on phases of activity from only five dated samples, but they all predate the appearance of the Late Bronze Age Colchian culture around the middle of the second millennium BC and, importantly, redate the earliest activity at the site by over two millennia.

Among the other OSL results (table 2) was one derived from a fragment of one of the double-headed zoomorphic figurines found in Trench A in 2014. These figurines (fig. 4), relatively dated by Georgian specialists to the eighth/seventh century BC (Lomitashvili et al. 2011), are ceramic artefacts and depict a variety of animals in a stylised form, which sometimes makes it impossible to identify the specific species portrayed. They each have a head and a pair of forelimbs at either end, joined by an elongated torso which is sometimes hollow and sometimes solid. The hollow torsos closely resemble air pipes from iron-smelting furnaces on display at the Givi Eliava Martvili Local Museum, $17 \mathrm{~km}$ east of Nokalakevi. Analysis of local clay samples has demonstrated that the mineralogical elements of the clay and the figurines are identical and, consequently, it can be supposed that the double-headed zoomorphic figurines were locally produced (Lomitashvili et al. 2011: 116-14; 2013: 212$23)$. The only known analogous figurines of this period in the southern Caucasus are found on the other side of the Colchian plain in Vani (Lortkipanidze 1995). The figurines found during the Anglo-Georgian Expedition excavations are represented by fragments featuring multiple or individual elements (including torsos, legs, heads, horns and snouts) with stylistic differences among them. The eyes and nostrils are all expressed by fine holes, and mouths on sub-cylindrical snouts are commonly indicated by a horizontal line, occasionally a deep cut. Teeth, where they are represented, were modelled with a comb-like tool. Rarely, the figurines feature other distinctive characteristics, modelled in relief, such as a horizontal ridge along the back, a hoop (perhaps a necklace or a collar) around the neck or a semicircular crest or mane behind the head. A rare opportunity arose in 2014 to take a sample from a fragment of figurine torso, and it was submitted for OSL dating (laboratory code X6678; table 2). Analysis produced a date range of 795-415 BC, which, in the absence of associated pottery from the sixth or fifth century BC, provides a useful confirmation of the stylistic/ relative dating arrived at.

Five ceramic samples were taken for OSL dating from Trench C during excavations in 2014 and 2015 (table 2). The first three were retrieved from a colluvial deposit (Trench C context 113) and were sampled in order to obtain absolute dates for the extent of the mixing of material from further up the slope. The scale of colluvial movement of sediment has been long observed at Nokalakevi, with significant deposits representing periods of different depositional characteristics. Bands of sediment with a higher density of fine limestone pebbles are interspersed with bands containing very few inclusions and bands with significant quantities of angular limestone

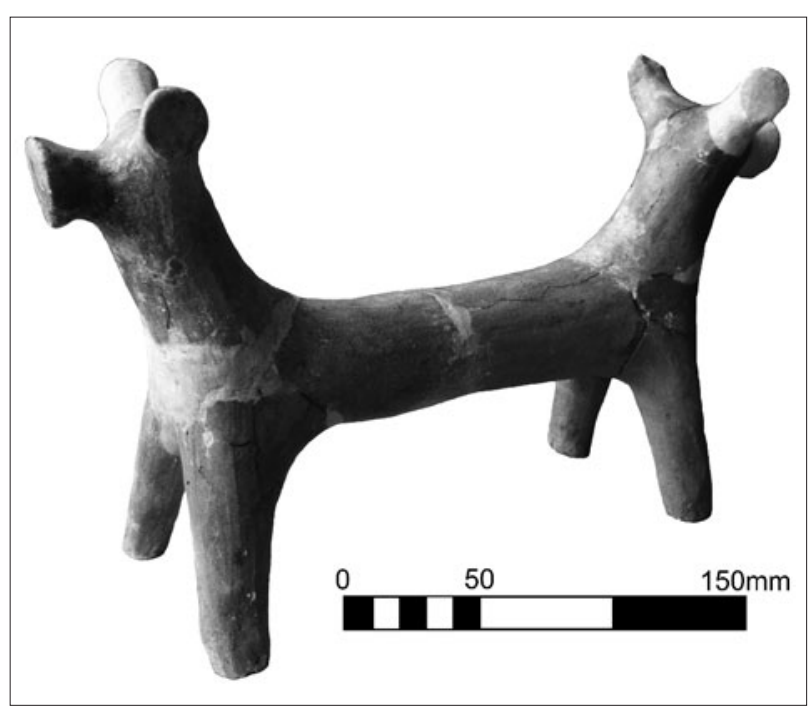

Fig. 4. An example of the double-headed zoomorphic figurines found at Nokalakevi. 
cobbles. Each band is clearly suggestive of shifting patterns of activity on the hillside, including, perhaps, varying levels of deforestation and exploitation. One common characteristic across the colluvial deposits, however, is the heavy mixing of material culture as artefacts from a number of different periods erode from archaeological contexts and are transported down the hill. Of the samples taken from the colluvial sediment it is interesting to note that, while one was most likely from the Hellenistic period (with the date range extending to the second century AD), two of the date ranges for the firing of the pottery postdate the early eighth century $\mathrm{AD}$, when Nokalakevi had shrunk significantly in size following the invasions of the Arab general Marwan ibn Muhammad. One sample produced a date within the range AD 7251045 and the other AD 1025-1265. As such, they also predate the redevelopment of the site as the seat of a branch of the princely Dadiani family around the 16th century. It seems possible, though somewhat speculative at this stage, that the colluvial activity that transported these fragments resulted from renewed exploitation of natural resources on the hillside during this later period of redevelopment. The remaining two samples from this trench will be discussed below in relation to the date and phasing of structures.

Two further samples were retrieved and analysed from the first season of excavation at the expedition's second site at Khuntsi, $25 \mathrm{~km}$ east of Nokalakevi, in 2015. The site had been identified as the possible location of the 'lost' fortress of Onoguris described by the historian Agathias in the sixth century AD (Historiarum Libri Quinque; Keydell 1967: II.22.3, III.3.8, III.4, III.5.6-III.8.2, IV.9.6, IV.11), and the first season involved the excavation of four test pits to assess the survival of archaeological deposits. One sample, from the context that also produced an unusual stamped motif on an amphora handle (fig. 5; Everill et al. 2017), revealed a date range of AD 485-805. The relative dating of this context, based on the wider assemblage and stylistic similarities between the stamped motif and

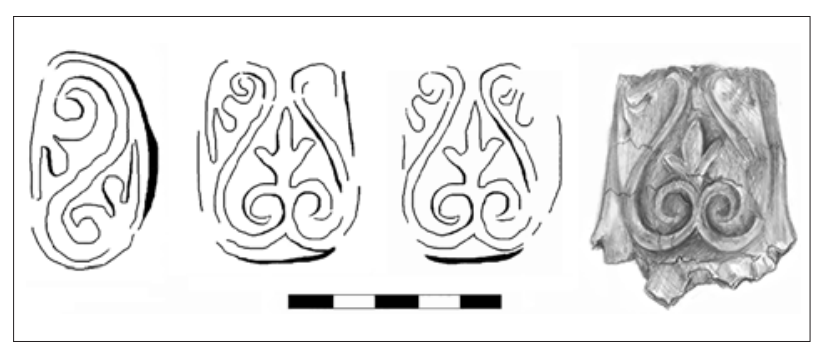

Fig. 5. The distinctive 'floral' amphora handle decorations. From left: a stylistically similar motif found during excavations at Nokalakevi in 1981; decorated amphora handles recovered from Khuntsi in 2015 and 2016; illustration of the 2016 example by S. Laitadze. another found outside the walls of Nokalakevi in the 1980 s, is the sixth century AD, which sits comfortably within the absolute date range. A second sample, taken from a layer thought to be directly overlying non-archaeological geological sediment, produced a date range of 1264-204 BC. This is the largest margin of error of any of the samples analysed, but is at least consistent with the artefactual evidence, which indicates initial activity at the site no later than the sixth century BC.

\section{The dates and phasing of structures}

Several structures were found in Trenches A and B between 2004 and 2010. Most were broadly dated to the Hellenistic period by association with ceramics, though some appeared to date to the sixth/fifth century BC, but all display the same physical characteristics. Lines of unbonded, undressed limestone boulders had been laid on the ground - presumably to provide a waterproof base to a timber frame in a very wet climate. From evidence in Trench B (Everill et al. 2014: 50), where a large section of burnt wall had collapsed, it appeared that a sill plate of a horizontal beam had been placed on the boulders, with vertical posts rising from it through which wattle was woven and then daub applied. Impressions of both wattle and the posts, the latter of about $100 \mathrm{~mm}$ diameter, were observed in larger fragments of burnt daub in both trenches, and a short $(0.7 \mathrm{~m})$ fragment of badly burnt beam was found across two of the boulders. The wall line revealed in Trench B was within $0.5 \mathrm{~m}$ of the northern extent of the trench, and as a result it was covered and left until it could be properly excavated. In 2016, the opening of a new trench at this location (Trench F) provided an opportunity to do just that, and subsequent investigation has revealed several further walls and surfaces, which may represent a significant, multilevel structure or phases of construction.

To date, seven samples of charcoal from burnt deposits have been collected and submitted for radiocarbon dating (table 3). All radiocarbon ages, including those derived from bone (below), were calibrated using the Oxford Radiocarbon Accelerator Unit calibration program OxCal 4 (Bronk Ramsey 2017), against the IntCal13 atmospheric calibration curve (Reimer et al. 2013). Calibrated date ranges are identified as cal. BC or cal. AD. Three samples, collected in 2007, were from a substantial deposit of burnt daub in Trench A (context 216), overlying the wall base of a small square structure. With all three samples taken from the burnt remnants of a single post, a chi-square test of the results led to one being excluded and the remaining two combined and processed to produce a single calibrated date range. Three further charcoal samples were taken from Trench F in 2016, one from a layer of burnt material (context 102) underlying a similar line of unbonded 


\begin{tabular}{lcccccc} 
Laboratory code & $\begin{array}{c}\text { Received } \\
\text { processed }\end{array}$ & Sample & Context and sample no. & $\begin{array}{c}\text { Age } \\
\left({ }^{4} \text { C years BP) }\right.\end{array}$ & $\begin{array}{c}\text { Error } \\
(1 \sigma)\end{array}$ & $\begin{array}{c}\text { Calibrated date } \\
(95.4 \% \text { probability })\end{array}$ \\
\hline BA071459 & $27 / 11 / 2008$ & Charcoal & NOK07/A (216) 13-1 & 2360 & 40 & \\
BA071460 & $27 / 11 / 2008$ & Charcoal & NOK07/A (216) 13-2 & 2430 & 35 & \\
BA071461 & $27 / 11 / 2008$ & Charcoal & NOK07/A (216) 13-3 & 2570 & 35 & \\
$\begin{array}{l}\text { The three samples above are from the same timber. BA071461 was } \\
\text { excluded following chi-square test; BA071459 and BA071460 combined: }\end{array}$ & 2400 & 35 & $750-395$ cal. BC \\
$\begin{array}{l}\text { SUERC-69307 } \\
\text { (GU41933) }\end{array}$ & $05 / 10 / 2016$ & Charcoal & NOK16/F (102) 1 & 2418 & 34 & $750-400$ cal. BC \\
$\begin{array}{l}\text { SUERC-69308 } \\
\text { (GU41934) }\end{array}$ & $05 / 10 / 2016$ & Charcoal & NOK16/F (105) 2 & 2237 & 34 & $390-200$ cal. BC \\
$\begin{array}{l}\text { SUERC-69309 } \\
\text { (GU41935) }\end{array}$ & $05 / 10 / 2016$ & Charcoal & NOK16/F (105) 5 & 2215 & 34 & $380-195$ cal. BC \\
$\begin{array}{l}\text { SUERC-81643 } \\
\text { (GU48787) }\end{array}$ & $11 / 09 / 2018$ & Charcoal & NOK18/F (134) 2 & 2183 & 28 & $360-170$ cal. BC
\end{tabular}

Table 3. Radiocarbon dates and calibrated dates for samples of burnt structural timber from Nokalakevi.

limestone blocks and two from burnt timber in a demolition deposit (context 105) apparently associated with the structure itself. The most recent sample, also from Trench $\mathrm{F}$, was taken from a discrete deposit contained within two walls - again visible as lines of unbonded limestone blocks - towards the north of the trench. This deposit (context NOK18/F 134) contained a significant quantity of charcoal and pottery, as well as a stone pestle, a three-tine technical fork and a non-local stone, transported naturally by the river Tekhuri, from where it was retrieved and used in bead production in the area. The deposit was therefore interpreted as representing a workshop. The results from all seven samples support the continuity of settlement indicated by the ceramic finds, and hint at an earlier foundation than previously thought, perhaps in the early sixth century BC. The number of phases observed through excavation and the results of the radiocarbon dating indicate near-continuous occupation in this part of the site well into the Hellenistic period, perhaps even the late third to early second century $\mathrm{BC}$.

In 2015 a sherd of pottery was sampled for OSL dating from an assemblage in Trench $\mathrm{C}, 150 \mathrm{~m}$ to the west of Trench B/F; it was lying in situ on a levelled deposit that seemed to represent a crude surface. This deposit was associated with a line of unbonded limestone blocks similar to those described above from Trenches A, B and F, though the blocks themselves were slightly smaller on average. Although the essential nature of the feature was undoubtedly similar, it incorporated reused ceramic tiles near a western terminus - perhaps functioning as a post pad - and these have not been found from the Hellenistic or earlier periods at Nokalakevi. With only $5 \mathrm{~m}$ of it exposed in the trench, it was difficult to draw any further conclusions regarding the form of the overall structure. Unfortunately, the margin of error associated with this sample is significant, meaning that the date for it cannot be determined in absolute terms - more accurately than the first millennium AD (table 2, laboratory code X6910). However, a second sample (table 2, laboratory code X6911), taken from a layer underlying the surface, produced an OSL date range of AD 206-526, which encompasses a period of significant activity at Nokalakevi and suggests a date for the structure that better fits the known expansion of the site in the early Byzantine period. This would certainly account for the presence of ceramic tiles and is particularly interesting because it demonstrates a continuity of local vernacular building practice. The use of unbonded and undressed limestone blocks as a waterproof wall base at the site can currently be seen in archaeological evidence from the sixth century BC to, perhaps, the sixth century AD. Similar principles can still be seen in regional examples of 19th- and early 20th-century structures, and in the development of the traditional Oda houses of Samegrelo - richly decorated timber buildings, resting on stone or concrete piles to keep the structure clear of wet ground.

The relationship between the burials and the structures of the Hellenistic period is perhaps key to understanding the character of the site; yet, because of the nature of the 
deposits, no grave cut is observed prior to discovering the burials. Consequently, the precise stratigraphic relationship has been unclear. The burials themselves display a remarkable variety, including flexed and supine inhumations, cremations and infant burials placed on deliberately modified ceramic vessels. Grave goods in this period most commonly consist of fine bead necklaces in a range of materials, copper-alloy bracelets and complete ceramic vessels at the head or feet. One adult male, discovered in Trench A, was buried with blue paste beads around his waist, a vessel at his feet and an entire chicken by his head. Analysis of the grave fill in 2009 revealed microscopic remains of bird feathers (Chichinadze and Kvavadze 2014: 119). Radiocarbon dating of this individual (SUERC89906) produced a date range of 390-200 cal. BC at 95.4\% probability (table 4), which post-dates the date range obtained from structural charcoal from the same trench (table 3). Furthermore, a sample from the rib of an individual excavated in Trench F in 2017 (SUERC-75786) was also radiocarbon dated, and, while the full ( $95.4 \%$ probability) calibrated date range covers almost the entire Hellenistic period (table 4), the range extends to $90 \mathrm{cal}$. $\mathrm{BC}$, almost a century after the most recent date obtained from structural charcoal from the same trench; therefore, it could also post-date nearby structures. If true, this supports the interpretation reached on the ground: that the burials post-date the buildings and that the settlement or areas of it were abandoned and instead used for burials set against the decaying walls of the earlier buildings. However, there remains the possibility that neonates, infants and even sub-adults might have been buried close to a family home. Thus, clearly more data, from both the structures and the burials, are required before firm conclusions can be drawn.

\section{Burials in the Christian period}

It is interesting to note that the different treatment of child burials does not appear to be limited to the pre-Christian period, with one individual (probably $<6$ yrs old, judging from the lack of permanent dentition: Bass 1995) excavated in Trench G (SUERC-81639) in 2018. This was radiocarbon dated to $610-690 \mathrm{cal}$. AD (table 4), by which time the church and cemetery were well established in Nokalakevi, and yet it was instead found associated with vernacular structural remains about $100 \mathrm{~m}$ east of the cemetery.

Three adult males had been found within a few metres of this location, side by side in Trench A, in 2005. They were considered interesting because, although buried in an ostensibly Christian manner, it was apparent that their burial had been rushed and lacked the usual care in laying them out. One interpretation at the time was that these were hastily buried casualties of the Persian attack on
Nokalakevi-Archaeopolis in AD 551; however, radiocarbon dating of one of the three (SUERC-89905) produced a date range of 660-770 cal. AD (table 4). The last Byzantine garrison at Archaeopolis - evidenced by Alfons Maria Schneider's 1930 discovery, in one of the towers, of 23 gold solidi - appears to have been in the reign of the Byzantine emperor Maurice at the end of the sixth century AD (Lomitashvili et al. 2014). Arab attacks on the southern Caucasus reached the western Georgian kingdom of Lazika a century later. Sources mention the invasions of the early and mid-eighth century, including that of the Arab general Marwan ibn Muhammad (governor of Arminiyya, known locally as Murvan the Deaf; he later assumed the dignity of caliph, becoming the last Umayyad caliph, Marwan II). As governor of Armenia, he attacked Georgia, including Lazika, in the 730s (Colvin et al. 2014) and some attribute the slighting of Nokalakevi's three walls to his forces. The date of these attacks certainly sits squarely within the radiocarbon date range for the individual, though it should be noted that no other evidence has been found to corroborate this interpretation.

The Church of the Forty Martyrs, built in the sixth century and still serving the local community today, has seen significant alterations over the centuries - as attested by the fascinating patchwork of masonry and ceramic building material which reveals, amongst other things, the insertion, filling and resizing of doors and windows. Its southern porch, once described as a chapel to the Forty Martyrs (Everill 2019: 216), is one such addition. In 2014 archaeological work sought to establish a date for this construction. Under the current paving stones, a number of round pilae were set in mortar to form the cover of a grave. Originally 40 in number, they were once thought to mark the remains of the martyrs themselves (Everill 2019: 219). Investigation has now shown that they had been disturbed by the digging of a small pit to conceal an icon frame in the 20th century. Within the grave, a single adult was found, and broadly dated to the eighth to tenth century $\mathrm{AD}$ by association with a buckle that is analogous to Bulgar examples from the river Volga (Lomitashvili et al. 2018). Radiocarbon dating of this individual (SUERC89907 ) produced a date range of 900-1030 cal. AD (table 4 ), and, as it is possible that the capped grave was an integral element of the southern porch, this might, therefore, provide a date for its construction.

The cemetery around the church was clearly an important aspect of the ecclesiastic precinct and the community it served, and was in use for centuries. Three individuals provide insight into its history. The intercutting nature of burials over a prolonged period, as is the case at Nokalakevi, can produce a very complex picture. The excavation in Trench B (and later in Trench F, immediately to the north; fig. 3) added further complexity through two 


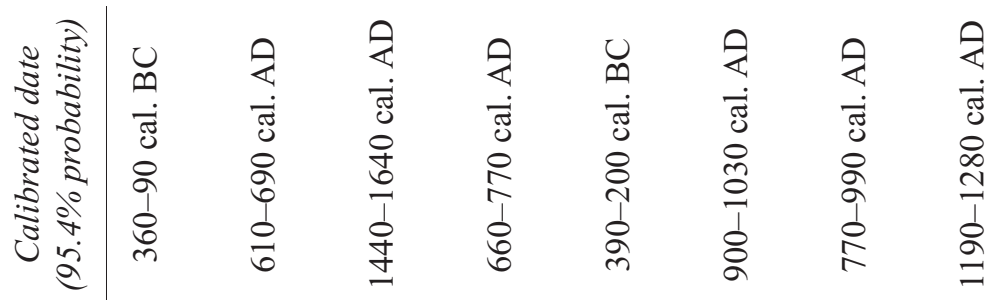

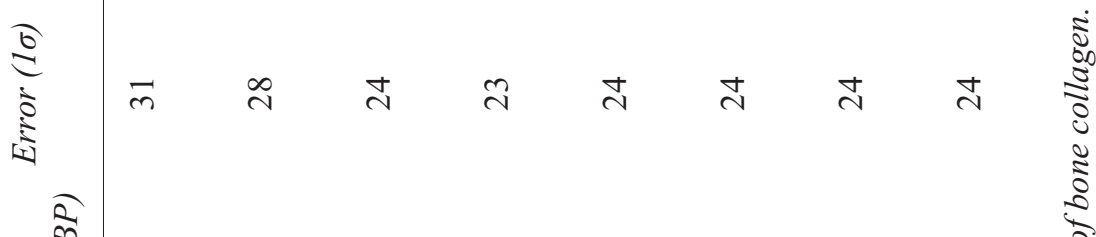

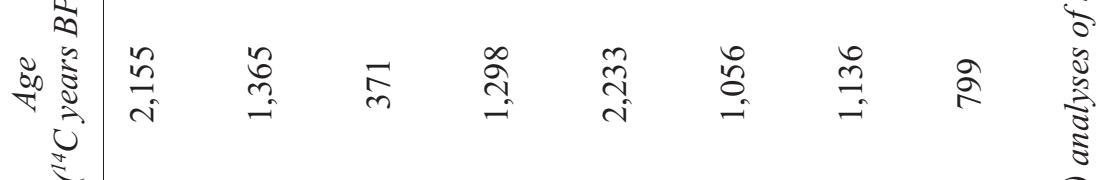

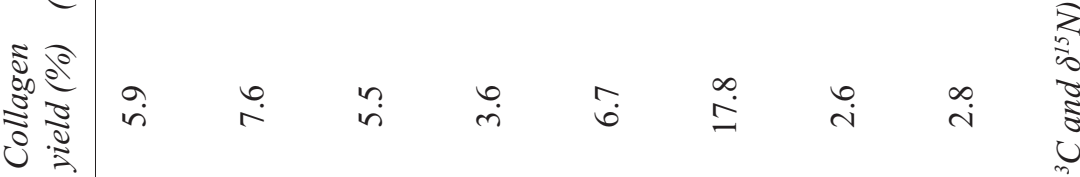

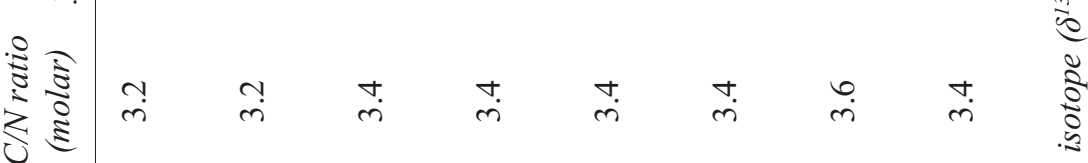

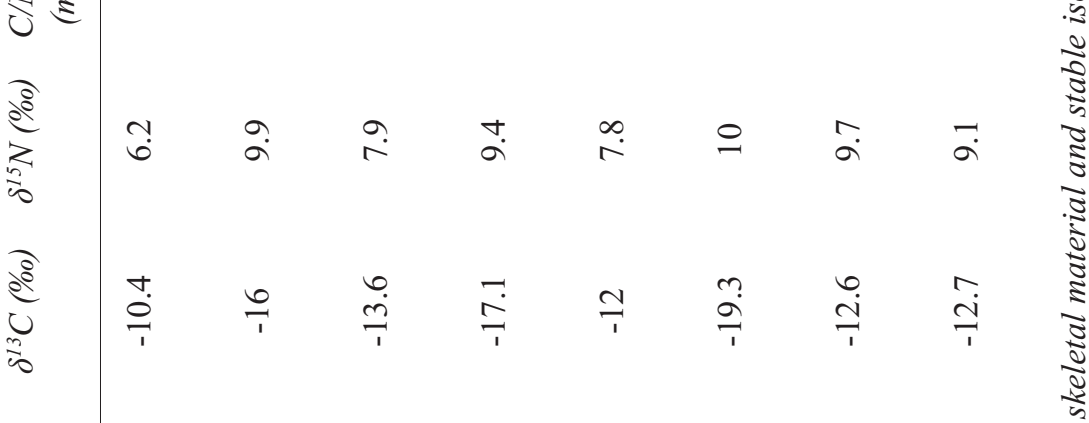

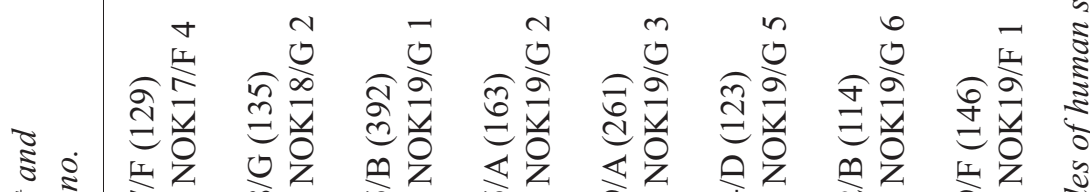

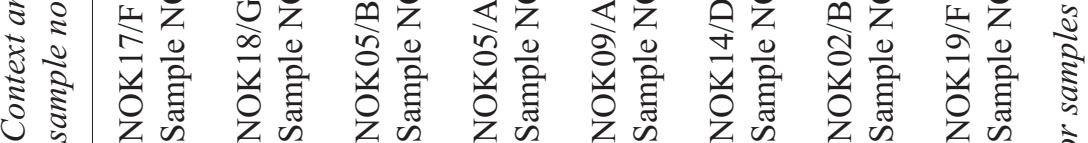

ن

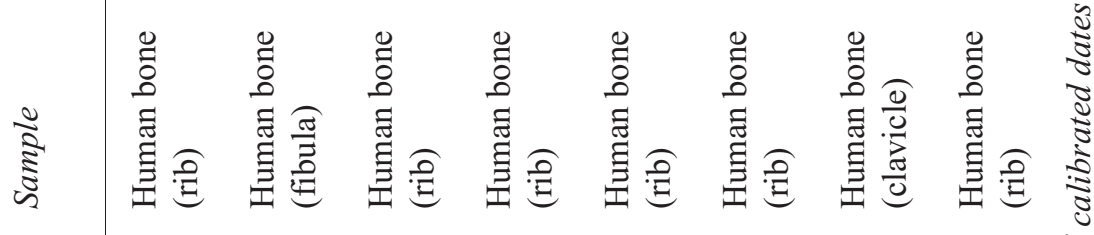

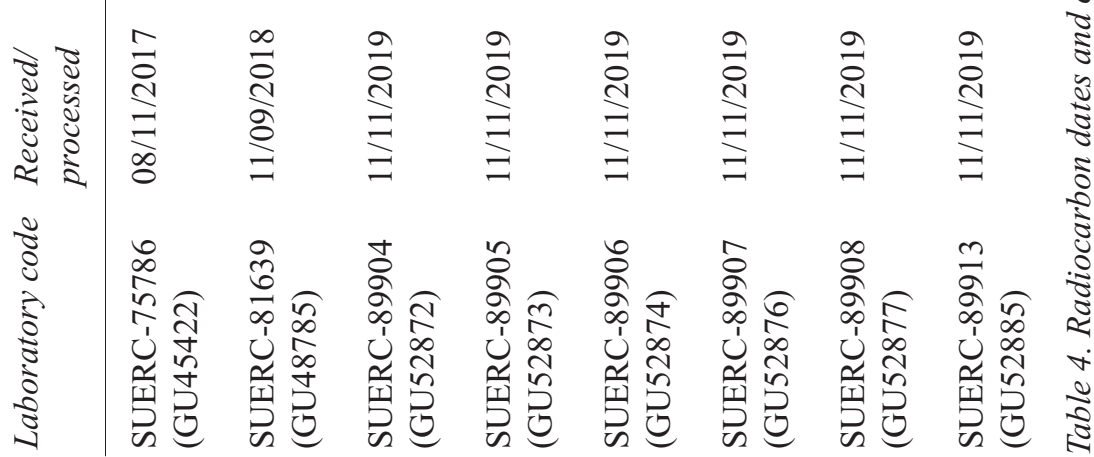


additional factors: firstly, only the northeastern corner of the walled cemetery enclosure was investigated and, secondly, it was not clear when this wall was constructed (i.e. when the cemetery enclosure was 'formalised'), though the wall was considered most likely to date to the 15 th/16th century AD. In 2002, the very first articulated adult burial revealed within the walled enclosure in Trench $\mathrm{B}$, a young adult female, had apparently disturbed the earlier burial of a young adult male, and a juvenile had been placed with her; though it was not clear whether that of the juvenile was a contemporary or subsequent burial, they were interpreted in the field as a family group. The female (SUERC-89908) produced a radiocarbon date range of 770-990 cal. AD.

While it has always been a possibility that the construction of the wall was later, and formalised a more ancient but less permanent boundary to the cemetery, a Christian burial was revealed in Trench F in 2019, well outside the walled enclosure, that challenged this interpretation. Although there have been a number of instances of disturbed/disarticulated human bone found north of the cemetery walls since 2002, this articulated adult female (SUERC-89913) was found approximately 20m north of the wall and submitted for laboratory analysis, producing a date range of 1190-1280 cal. AD (table 4). She was carefully laid out in a Christian manner and, other than the additional distance from the church, there was nothing noteworthy about the burial. The implication is clearly that the boundary of the cemetery had not been formalised at this time or, if it had, it was considerably larger than the area defined by the wall.

In 2003 and 2005 three burials were excavated in the extreme northeastern corner of the walled enclosure. They are noteworthy in a number of regards. They were orientated north-south, with the heads at the north and the feet in the direction of the Tekhuri river to the south. Once again, they appear to represent a family group, consisting of a middle-aged male and female, and a neonate. The placement of the neonate suggests that it, at least, must have been buried after the wall was constructed, being located so close to the base of the wall that the fragile remains would not have survived in articulation had the wall been constructed subsequently. A radiocarbon date was obtained for the female (SUERC-89904), producing a range of 1440-1640 cal. AD. By this period, western Georgia was securely within the Ottoman sphere of influence. While the Turkish traveller Çelebi (1834: 197) describes the inhabitants of Samegrelo as still a Christian 'tribe' in the mid-17th century, there were some who served in the Ottoman army and, presumably, some conversions to Islam, as well as an increase in the mobility of traders and merchants from across the Ottoman world. While it is more common in Islamic burial practice for the head to be turned to the right facing Mecca, therefore determining the orientation of the body, 'other orientations were acceptable as long as the face, the head, or feet were oriented toward Mecca' (Shingiray 2018: 97; see also Petersen 2013). If, as seems likely, these individuals were Muslim, with their feet orientated towards Mecca, it is interesting to note that they had been accorded a place in the otherwise Christian cemetery by the rest of the community. This seems to suggest a degree of community integration and diversity, or at least a pragmatic acceptance of the political and cultural situation, though the group was still buried in a corner of the (perhaps newly) formalised cemetery enclosure, as far from the church as possible.

\section{Diet}

Stable isotope measurements have been obtained from eight human burials to date, with collagen extracted from samples as a partially hydrolysed fraction (gelatine) and then freeze-dried. Approximately $0.6 \mathrm{mg}$ of collagen was weighed into a tin capsule for stable isotope analysis $\left({ }^{13} \mathrm{C}\right.$ and ${ }^{15} \mathrm{~N}$ and $\mathrm{C} / \mathrm{N}$ ratio) using a Delta $\mathrm{V}$ Advantage continuous-flow isotope ratio mass spectrometer coupled to an IsoLink elemental analyser via a Conflo IV TM (Thermo Scientific, Bremen, Germany). The samples were combusted in a single reactor containing tungstic oxide and copper wires at $1020^{\circ} \mathrm{C}$ to produce $\mathrm{N}_{2}$ and $\mathrm{CO}_{2}$. The gases were separated in a $0.8 \mathrm{~m} \mathrm{GC}$ column heated to $70^{\circ} \mathrm{C}$. Helium was used as a carrier gas throughout the procedure. $\mathrm{N}_{2}$ and $\mathrm{CO}_{2}$ entered the mass spectrometer via an open split arrangement within the Conflo IV IV and were analysed against their corresponding reference gases. For every ten unknown samples, in-house gelatine standards, which are calibrated to the international reference materials USGS40, USGS41, IAEA-CH-6, USGS25, IAEA-N-1 and IAEA-N-2, were run in duplicate. Results are reported as per mil (\%o) relative to the internationally accepted standards VPDB and AIR with $1 \sigma$ precisions of better than $\pm 0.1 \%$ for $\delta^{13} \mathrm{C}$ and better than $\pm 0.2 \%$ for $\delta^{15} \mathrm{~N}$.

Stable isotope analysis of the bone collagen from a rib of one of the Hellenistic burials mentioned above NOK $17 / F(129)$ - demonstrated that the $\delta^{13} \mathrm{C}$ relative to VPDB measured $-10.4 \%$; while the $\delta^{15} \mathrm{~N}$ relative to air measured 6.2\%o (SUERC-75786; table 4). The results indicate that $\delta^{13} \mathrm{C}$ is surprisingly high while $\delta^{15} \mathrm{~N}$ is lower than normal. In order to check that the results were reliable, the laboratory subsequently measured the $\delta^{13} \mathrm{C}$ in two different instruments and got the same result. As a final check, the root of a molar was also tested, and produced a similar result. The implications of this dietary signal are that this individual had a diet composed almost entirely of $\mathrm{C} 4$ plants or animals fed $\mathrm{C} 4$ crops, but with the emphasis on the former. Of these species (which include 
maize, sugarcane and sorghum) millet is well known as one of the dietary staples in ancient western Georgia (see, e.g., Procopius History of the Wars 8.13) - being better suited to long-term storage in humid conditions than other grains. David Braund observes that

There was no lack of grain in Lazica, nor lack of legumes. However, the most commonly eaten grain there was not wheat, but millet, as Procopius knew. The millet was probably prepared as a sort of polenta, as in later centuries: this dish, called gomi, remains one of the pillars of the cuisine of the region, though it is now made from maize (1991: 222).

Large quantities of carbonised seeds of broomcorn millet (Panicum miliaceum) and foxtail millet (Setaria italica), as well as common wheat (Triticum aestivum s.1.), were observed in the analysis of samples from Hellenistic period burials found at Nokalakevi between 2007 and 2010 (Bokeria 2014: 98). The burnt remnants of a possible millet porridge were also found in a vessel, perhaps deposited as a component of a funerary meal (Bokeria 2014: 108). Evidence for the importance of millet in the sixth/fifth century BC was also found during excavations at the site of Vani, across the Colchian plain, where amphorae were filled with broomcorn millet grains and placed under an altar (Lordkipanidze 1966). Despite the fact that wheat and other $\mathrm{C} 3$ cereals were clearly grown in the Hellenistic period, the data support historical descriptions of the importance of millet for both human food and animal fodder in western Georgia, perhaps because it was better suited for storage in the humid conditions that characterise the region.

Indeed, C4 plants clearly feature in the diet of nearly all of those individuals analysed. The results closest to those described above were found in the other Hellenistic individual (SUERC-89906; table 4) - the male buried with beads, a ceramic vessel and an entire chicken. The $\delta^{13} \mathrm{C}$ value $(-12 \%)$ is still high and indicates that his diet was dominated by $\mathrm{C} 4$ plants; however, the slightly increased $\delta^{15} \mathrm{~N}$ value (7.8\%) potentially suggests that a little more was being consumed via animals fed on $\mathrm{C} 4$ plants.

Alongside the evidence of this dietary pattern in the Hellenistic period, it is interesting to note that the results from the two burials from the seventh century or the first half of the eighth century AD - the period contemporary with or just prior to the invasions of western Georgia by the Arab general Marwan ibn Muhammad - appear to indicate a similar diet. These two burials - NOK18/G (135) (SUERC-81639) and NOK05/A (163) (SUERC$89905)$ - have significantly lower $\delta^{13} \mathrm{C}$ values $(-16.0 \%$ and $-17.1 \%$, respectively), indicating a much more varied diet that included both $\mathrm{C} 3$ and $\mathrm{C} 4$ plant-based resources. They both also produced higher $\delta^{15} \mathrm{~N}$ values (9.9\%o and $9.4 \%$, respectively), suggesting an increased contribution via meat or dairy.

The centuries that followed may well, in turn, be characterised by two further individuals: NOK02/B (114) (SUERC-89908) and NOK19/F (146) (SUERC-89913). These two produced much higher $\delta^{13} \mathrm{C}$ values $(-12.6 \%$ and $-12.7 \%$, respectively) that appear to indicate a renewed dominance of $\mathrm{C} 4$ plants in the local diet, closer to the results seen in the Hellenistic period, but $\delta^{15} \mathrm{~N}$ values (9.7\% and $9.1 \%$, respectively) that indicate continued meat/dairy consumption. While it might be tempting to interpret a return to a dependence on $\mathrm{C} 4$ plants in this period as indicative of economic difficulty, it should be noted that the period covered includes the zenith of the Golden Age of Georgia, during the reign of Queen Tamar the Great (r. 1184-1213); thus cultural or climatic drivers for this change might be more likely.

The most recent burial to be studied dates from the 15th-17th century AD: NOK05/B (392) (SUERC-89904). The $\delta^{13} \mathrm{C}$ value of $-13.6 \%$ remains markedly higher than the results from before the Arab invasions. This suggests that $\mathrm{C} 4$ plants remained the dominant crop in the local economy for many centuries; however, the consumption of dairy and meat (indicated by a $\delta^{15} \mathrm{~N}$ value of $7.9 \%$ ) is at its lowest level since the results seen for the Hellenistic individuals. In a description reminiscent of Procopius, the Turkish traveller and writer Çelebi wrote in the 17th century that 'corn and wheat are scarce as hardly any thing but millet and Lazúd (?) is sown' in Samegrelo (1834: 197). Although the translator, Joseph von Hammer, inserted a question mark at this point, M.E. Meeker observes that 'Lazúd is today the word for maize in the rural areas of Turkey's eastern Black Sea coast' and that maize had become an important crop in the region by the early 17th century (Meeker 1971: 328). It is interesting to note at this point that both millet and maize are $\mathrm{C} 4$ crops, and therefore either of them could be responsible for the high $\delta^{13} \mathrm{C}$ value in this individual, but that perhaps maize - the primary crop of today's villagers in Nokalakevi was already replacing millet as a dietary staple at this time.

The final results to be discussed represent a unique dietary pattern in the context of the individuals from Nokalakevi that have been studied to date. The adult in question, dated to AD 900-1030 and accorded the honour of burial immediately next to the Church of the Forty Martyrs - NOK14/D (123) (SUERC-89907) - is the only individual to produce a $\delta^{13} \mathrm{C}$ result that indicates a dominance of $\mathrm{C} 3$ plants (-19.3\%o) and also produced the highest $\delta^{15} \mathrm{~N}$ value (10\%), indicative of higher levels of meat or dairy in his diet. While these differences could demonstrate a higher socio-economic standing for this individual, it seems more likely - if one accepts the 
hypothesis put forward above that the return to a local dependence on $\mathrm{C} 4$ plants was cultural or climatic in origin - that this diet could be a marker of an individual from a different culture or locality.

\section{Population movement}

Particular interest is placed upon the extent to which population movement impacted on the modern territory of Georgia, in terms of the population itself but also the material culture. The emergence and refinement of strontium isotope analysis over the last 30 years (Bentley 2006) has provided an invaluable tool in terms of assessing the mobility of ancient people. Strontium isotopes released from local geology and into the food chain become incorporated into the human skeleton, and analysis by mass spectrometry of dental enamel can identify if the strontium signature that formed in childhood differs from the biologically available strontium at the archaeological site. Furthermore, the complex geology of the Caucasus region means that bioavailability of strontium should vary considerably within relatively small geographical areas, with both the age and character of the rock affecting the strontium levels and isotope ratios.

The Greater Caucasus mountain range that defines Georgia's northern border consists of Mesozoic to Neogene igneous and sedimentary rocks (Laermanns et al. 2018). The Tekhuri river which flows through Nokalakevi has its source in the northern high mountain zone, where the mountains are composed of breccia, tufas and porphyrite strata. Nokalakevi itself is situated towards the southern edge of a band of Neogene geology, including clays, sandstones, conglomerates and limestones, which forms a strip of hills on the edge of the plain and is known as the northern Kolkheti foothill hillock relief (Tielidze et al. 2019: 193). The Odishi plateau is a morphologically distinct subsection of this relief, situated between the Enguri river and the Tskhenistskali river (Tielidze et al. 2019: 195), and is further subdivided into a series of hills, including Unagira. The Unagira hill is itself divided into individual sectors including, among others, Eki mountain overlooking the town of Senaki and Nokalakevi mountain, and much of this area is characterised by limestone gorges and ravines (Tielidze et al. 2019: 196).

The Neogene geology of Nokalakevi is bounded 40km to the north by a narrow band $(<5 \mathrm{~km})$ of Palaeogenic geology (including clays, sandstones, marls and limestones), which marks the point at which the hilly relief on the edge of the intermountain lowland zone of the Colchian/Kolkheti plain gives way to the mountains (Tielidze 2019). Beyond this point, to the north, successively older geological formations have been exposed through the tectonic activity that created the mountain range. Immediately to the south of Nokalakevi, the
Colchian plain is dominated by Quaternary gravelite sandstones and clays, with a relatively narrow exposure of Neogene geology in the hilly relief at its southern edge. The southern mountain zone of the Lesser Caucasus is characterised predominantly by exposure of Palaeogene geology, with areas along Georgia's southern border dominated by Neogene and Quaternary igneous geology (Tielidze 2019). As a result, the bioavailability of strontium should vary between the Neogene geology of the northern Kolkheti foothills (within which Nokalakevi is situated), the plain itself and the foothills on the southern side of the plain.

All the teeth submitted for laboratory testing were prepared in the same way. The crown was separated from the root and placed in a $10 \mathrm{M} \mathrm{NaOH}$ solution and heated to approximately $80^{\circ} \mathrm{C}$ for eight hours and then allowed to cool. The dentine was scraped from the enamel using a dissecting needle and the procedure repeated until all the dentine had been removed. The sample was then repeatedly rinsed with $0.5 \mathrm{M} \mathrm{HCl}$ to remove all traces of the $\mathrm{NaOH}$ and finally rinsed with ultra-pure water. The isolated enamel sample was then oven dried overnight and transferred to a labelled glass vial to await analysis. Strontium was isolated from the enamel samples using conventional cation exchange methods and loaded onto single $\mathrm{Re}$ filaments using a $\mathrm{Ta}_{2} \mathrm{O}_{5}$ activator for mass spectrometry. The total procedural blank was $<200 \mathrm{pg}$. The samples were analysed on a VG Sector 54-30 mass spectrometer operated in dynamic (three cycle) multi-collection mode. Instrumental mass fractionation was corrected to ${ }^{86} \mathrm{Sr} /{ }^{88} \mathrm{Sr}=0.1196$ using an exponential fractionation law. Data were collected as 12 blocks of 10 ratios. NIST SRM-987 was used as a quality-control monitor.

The starting point for such analysis of material from Nokalakevi was to obtain and analyse teeth from three modern piglets. Local agricultural practice is non-industrialised, meaning that livestock is rarely transported and pig feed, primarily waste from locally grown and prepared meals or, for younger animals, milk from mothers fed on such scraps, is far more likely to represent an accurate measure of bioavailable strontium than elsewhere. Furthermore, the diet and amino acid requirements of domestic pigs are sufficiently similar to humans that they provide a good reference point to define the local ${ }^{87} \mathrm{Sr} /{ }^{86} \mathrm{Sr}$ range for human populations (Bentley 2006: 158). Analysis of the three pig teeth returned very similar strontium isotope ratios of $0.70809,0.70805$ and 0.70801 (with $2 \sigma$ absolute errors, respectively, of 0.00002 [GU52878], 0.00003 [GU48788] and 0.00004 [GU48789]; see table 5). These are relatively low values in line with results from younger, sedimentary rock in Germany (Bentley, Knipper 2005) and Great Britain (Evans et al. 2018), and reflecting Nokalakevi's location on geology characterised by Neogene limestone and marls. 
A study of sheep mobility during the Neolithic at Çatalhöyük (Bogaard et al. 2014) observed that modern strontium bioavailability on the adjacent Konya plain was greater than on the Neogene limestone terrace, the latter with an estimated ${ }^{87} \mathrm{Sr} /{ }^{86} \mathrm{Sr}$ ratio of around 0.7080 (Bogaard et al. 2014: 864; based on McArthur et al. 2001). The alluvial deposits of the Konya plain are fed from sources, including the Taurus mountains, 'composed of older (Mesozoic) limestones and other, more radiogenic substrates, including siliciclastics and metamorphic rocks' (Bogaard et al. 2014: 864). It is reasonable to suggest, therefore, that the Neogene geology of the Odishi plateau would also have lower ratios relative to the alluvium of the Colchian/Kolkheti plain, though a programme of research based on modern vegetation is required in order to confirm this hypothesis.

While recognising that more control samples are required to characterise properly the strontium signature for Nokalakevi and its environs, nine human molars - eight taken from burials described above and one from a burial for which radiocarbon dating failed - have thus far been submitted for testing. Based on results from modern piglets (0.70801-0.70809) and a predicted strontium ratio range for Neogene geology (McArthur et al. 2012) that extends from approximately 0.7080 to approximately 0.7090 , five of these individuals produced results immediately compatible with having been born and raised in or around Nokalakevi (table 5). These are, chronologically: the fourth- to third-century BC adult buried with beads, fine ceramics and a chicken (context 261); an adult burial from Trench A, which was dated by material culture to the Hellenistic period, but for which no radiocarbon date could be established; the child excavated in Trench G in 2018, radiocarbon dated to $610-690 \mathrm{cal}$. AD; one of the three adult males from Trench A, apparently buried hastily in 660-770 cal. AD; the adult female buried north of the later cemetery enclosure in 1190-1280 cal. AD.

Three further burials produced results that are close enough to this predicted range that they might indicate early life in or around Nokalakevi. While these results sit within a range predicted for Palaeogene geology (McArthur et al. 2012), it should be stressed that this work is based solely on the geology itself. The results of that study do not necessarily reflect the bioavailable strontium ratios, as Amy Bogaard and colleagues (2014) established in Turkey, and are therefore used simply as a guide until the hypothesis can be tested through further analysis of bioavailable strontium in the area and a detailed local model established. Indeed, the work of R.A. Bentley and C. Knipper (2005) in Germany relates higher ratios with older geology, as the radioactive decay of ${ }^{87} \mathrm{Rb}$ produces higher ratios of ${ }^{87} \mathrm{Sr} /{ }^{86} \mathrm{Sr}$ over time, however the scale of strontium bioavailability is dependent on strontium ions getting into solution and entering the food chain.
The three individuals that produced results just below the ${ }^{87} \mathrm{Sr} /{ }^{86} \mathrm{Sr}$ benchmark of 0.7080 are: the young adult female, part of the group in the Christian cemetery in Trench B (0.70795); the female orientated north-south in Trench B (0.70794); the Hellenistic individual from Trench F (0.70787).

One burial (GU-52883) stands out, however, for producing a strontium result that is sufficiently removed from both the modern samples from Nokalakevi itself and from the predicted ranges for Neogene geology. The individual who was buried most prominently, under the southern porch of the Church of the Forty Martyrs, returned a strontium result of 0.70743 . This sits within the range predicted by McArthur et al. 2012 for Cretaceous geology, but perhaps more likely reflects the impact of a range of geology, including igneous, on the alluvial deposits of the nearby Colchian/Kolkheti plain. It might, of course, indicate an individual raised in a different geological landscape, such as the Caucasus mountains. The buckle associated with this tenth- or early 11thcentury burial has analogies with examples found in the historic Bulgar state along the river Volga, and the strontium result suggests a greater degree of mobility than seen in the rest of the individuals analysed. While the data need further refining, particularly through more detailed analysis of bioavailable strontium in the region, this is a hugely important first step for the study of past populations at Nokalakevi and the dataset will continue to grow in the coming years.

\section{Conclusion}

Clearly, work is ongoing at Nokalakevi and will continue for many years yet. The analysis presented here is simply the start of a process that will continue throughout the lifetime of the project, but already the results are helping to shed more light on the long period of human activity represented at the site. In some cases, this might simply be to confirm dates produced by stylistic/typological analysis of ceramics, but others provide exciting, new insights.

In the absence of organic material for radiocarbon dating, optically stimulated luminescence (OSL) dating of ceramics has provided evidence that supports the stylistic and relative dating of the double-headed zoomorphic figurines to the eighth to seventh century $\mathrm{BC}$ and opened new lines of enquiry with regard to the colluvial movement of sediments. In terms of new research at the nearby site at Khuntsi, it has provided evidence that supports the relative dating of a sixth-century $\mathrm{AD}$ amphora stamp found associated with the fortified site, strengthening the case for it being the 'lost' fortress of Onoguris. Most excitingly, the application of OSL dating to five sherds from the earliest contexts in three different trenches clearly indicates Bronze Age activity at Nokalakevi. With no structural 


\begin{tabular}{lllllc} 
Laboratory code & Sample & Sample ID & Context & ${ }^{87}$ Sr $^{86}$ Sr & 2 $\sigma$ absolute error \\
\hline GU48788 & Pig tooth & NOK18 Modern Piglet 1 & Unstratified & 0.70805 & 0.00003 \\
GU48789 & Pig tooth & NOK18 Modern Piglet 2 & Unstratified & 0.70801 & 0.00004 \\
GU52878 & Pig tooth & NOK19 Modern Piglet 3 & Unstratified & 0.70809 & 0.00002 \\
GU48786 & Human tooth (M1) & NOK18/G 1 & NOK18/G (135) & 0.70816 & 0.00003 \\
GU45423 & Human tooth (M1) & NOK17/F 3 & NOK17/F (129) & 0.70787 & 0.00004 \\
GU52879 & Human tooth (M1) & NOK19/G 1 & NOK05/B (392) & 0.70794 & 0.00002 \\
GU52880 & Human tooth (M1) & NOK19/G 2 & NOK05/A (163) & 0.70803 & 0.00002 \\
GU52881 & Human tooth (M1) & NOK19/G 3 & NOK09/A (261) & 0.7081 & 0.00002 \\
GU52882 & Human tooth (M1) & NOK19/G 4 & NOK07/A (227) & 0.70809 & 0.00002 \\
GU52883 & Human tooth (M1) & NOK19/G 5 & NOK14/D (123) & 0.70743 & 0.00002 \\
GU52884 & Human tooth (M1) & NOK19/G 6 & NOK02/B (114) & 0.70795 & 0.00002 \\
GU52886 & Human tooth (M1) & NOK19/F Sample 1 & NOK19/F (146) & 0.70892 & 0.00002
\end{tabular}

Table 5. Results of strontium isotope analysis of modern piglet teeth and human teeth from archaeological deposits at Nokalakevi.

evidence from this period found to date, it is impossible to be sure of the extent of human activity in this period, but the analysis has pushed back the earliest archaeological evidence from the site by over two millennia.

In combination with radiocarbon dating, OSL results have demonstrated the continuity of vernacular building practices at Nokalakevi from the sixth century BC to perhaps the sixth century $\mathrm{AD}$, with some modifications over that period such as the later incorporation of ceramic tiles. The use of unbonded limestone blocks as waterproof wall bases is known to have continued into the early 20th century in Samegrelo, but this is the first time that absolute dates, derived from multiple techniques, have evidenced the longevity of this tradition in archaeological remains. In addition, radiocarbon dating of burnt timber associated with the structures is enabling a better understanding of the earlier phases of settlement in the lower town, demonstrating a continuity of occupation from the early sixth century $\mathrm{BC}$ through to the third or perhaps even the early second century BC. More carbon dates are required from the human remains in order to be sure of the relationship between the burials and structures of the Hellenistic period; however, it seems possible that, while the very young may have been buried close to home, the burial of older individuals took place after the buildings had gone out of use.
Stable isotope analysis using $\delta^{13} \mathrm{C}$ and $\delta^{15} \mathrm{~N}$ as dietary indicators supports historical accounts of the regional dependence on millet and, later, maize (both of which are C4 plants) as dietary staples. The data also reveal apparent changes over time in terms of the extent to which $\mathrm{C} 4$ plants dominated the diet. Similarities observed between the diets of the Hellenistic and medieval periods perhaps reflect climatic conditions or socio-economic drivers, but $\mathrm{C} 4$ plants represent a major food source throughout the periods for which there are data. Strontium isotope analysis of a number of individuals, alongside modern piglet teeth as a reference point, strongly suggests that the majority were born and raised in the local area. It is particularly noteworthy that the individual who produced an outlying (i.e. non-local) strontium isotope ratio result is also the only one for whom $\mathrm{C} 4$ plants were not a significant dietary contributor.

The Anglo-Georgian Expedition is not the first to apply scientific dating and analysis to an archaeological site in the southern Caucasus. However, what perhaps makes this project remarkable is the breadth of techniques employed and the variety of data that they make available. Having established the contribution that these approaches can make to the understanding of Nokalakevi, future goals will be to expand the datasets to shed further light on population movement, diet, phases and/or continuity of settlement. 


\section{Acknowledgements}

The scientific analyses reported in this paper were only possible thanks to financial support received from the University of Winchester. The Anglo-Georgian Expedition to Nokalakevi is also extremely grateful to the National Agency for Cultural Heritage Preservation of Georgia for its significant and ongoing support. We wish to acknowledge gratefully the important contribution made to our understanding of the site by those specialists who came before us, and we would also like to extend our thanks to all those who have participated in excavations at Nokalakevi - particularly to the more than 250 students from Georgia, Britain and elsewhere who have taken part in the Expedition since 2001. Finally, the Anglo-Georgian Expedition to Nokalakevi is grateful to the British Institute at Ankara and the British Academy Black Sea Initiative, which helped support our early seasons, and to the reviewers and all those who helped improve this paper.

\section{Bibliography}

Aitken, M.J. 1998: Introduction to Optical Dating. Oxford, Oxford University Press

Bass, W.M. 1995: Human Osteology: A Laboratory and Field Manual (4th edition). Columbia, Missouri Archaeological Society

Bentley, R.A. 2006: 'Strontium isotopes from the earth to the archaeological skeleton: a review' Journal of Archaeological Method and Theory 13.3: 135-87. https://doi.org/10.1007/s10816-006-9009-x

Bentley, R.A., Knipper, C. 2005: 'Geographical patterns in biologically available strontium, carbon and oxygen isotope signatures in prehistoric SW Germany’ Archaeometry 47.3: 629-44. https://doi.org/10.1111/j.1475-4754.2005.00223.x

Bogaard, A., Henton, E., Evans, J.A., Twiss, K.C., Charles, M.P., Vaiglova, P., Russell, N. 2014: 'Locating land use at Neolithic Çatalhöyük, Turkey: the implications of ${ }^{87} \mathrm{sr} /{ }^{86} \mathrm{sr}$ signatures in plants and sheep tooth sequences' Archaeometry 56.5: 860-77. https://doi.org/10.1111/arcm.12049

Bokeria, M. 2014: 'Archaeobotanical analysis of samples from Nokalakevi' in P. Everill (ed.), Nokalakevi - Tsikhegoji - Archaeopolis: Archaeological Excavations 2001-2010: Anglo-Georgian Expedition to Nokalakevi. Oxford, Archaeopress: 97-110. https://doi.org/10.30861/9781407312439

Braund, D. 1991: 'Procopius on the economy of Lazica' The Classical Quarterly 41.1: 221-25. https://doi.org/10.1017/s0009838800003682

Bronk Ramsey, C. 2017: 'Methods for summarizing radiocarbon datasets' Radiocarbon 59.2: $1809-33$. https://doi.org/10.1017/rdc.2017.108

Çelebi, E. (tr. J. von Hammer) 1834: Narrative of Travels in Europe, Asia, and Africa in the Seventeenth Century by Evliyá Efendí 2. London, Oriental Translation Fund. https://doi.org/10.1017/cbo9781139152006.034

Chichinadze, M., Kvavadze, E. 2014: 'Palynological analysis of samples taken from vessels and burials in 2009' in P. Everill (ed.), Nokalakevi - Tsikhegoji-Archaeopolis: Archaeological Excavations 2001-2010: Anglo-Georgian Expedition to Nokalakevi. Oxford, Archaeopress: 111-120. https://doi.org/10.30861/9781407312439

Colvin, I., Lortkipanidze, B., Murgulia, N. 2014: 'Historical overview of Colchis-Egrisi-Lazika' in P. Everill (ed.), Nokalakevi - Tsikhegoji - Archaeopolis: Archaeological Excavations 2001-2010: Anglo-Georgian Expedition to Nokalakevi. Oxford, Archaeopress: 1-12. https://doi.org/10.30861/9781407312439

Dubois de Montpéreux, F. 1839: Voyage autour du Caucase, chez les Tcherkesses et les Abkhases, en Colchide, en Géorgie, en Arménie et en Crimée 3. Paris, Librairie de Gide

Evans, J.A., Chenery, C.A., Mee, K., Cartwright, C.E., Lee, K.A., Marchant, A.P., Hannaford, L. 2018: Biosphere Isotope Domains GB (V1): Interactive Website. British Geological Survey: https://doi.org/10.5285/3b141dce-76fc-4c5496fa-c232e98010ea

Everill, P. (ed.) 2014: Nokalakevi - Tsikhegoji-Archaeopolis: Archaeological Excavations 2001-2010: Anglo-Georgian Expedition to Nokalakevi. Oxford, Archaeopress. https://doi.org/10.30861/9781407312439

— 2019: 'Travellers' tales of Mingrelia and of the ancient fortress of Nokalakevi' Ancient West \& East 18: 195-224

Everill, P., Lomitashvili, D., Tvaradze, A., Neil, B., James, L., Russel, C. 2014: 'AGEN Trench B results: 2002-2010' in P. Everill (ed.), Nokalakevi - Tsikhegoji-Archaeopolis: Archaeological Excavations 2001-2010: Anglo-Georgian Expedition to Nokalakevi. Oxford, Archaeopress: 43-54. https://doi.org/10.30861/9781407312439

Everill, P., Lortkipanidze, B., Murghulia, N., Colvin, I., Lomitashvili, D. 2017: 'The lost fortress of Onoguris? Recently discovered 6th century AD fortifications at Khuntsistsikhe, west Georgia' Antiquity 91.356: E5. https://doi.org/10.15184/aqy.2017.1

Keydell, R. 1967: Agathias: Historiarum Libri Quinque. Berlin, de Gruyter

Laermanns, H., Kelterbaum, D., May, S.M., Elashvili, M., Opitz, S., Huille, D., Rölkens, J., Verheul, J., Riedesel, S., Brückner, H. 2018: 'Mid-to late Holocene landscape changes in the Rioni delta area (Kolkheti lowlands, W Georgia)' 
Quaternary International 465 (part A): 85-98. https://doi.org/10.1016/j.quaint.2016.12.037

Lomitashvili, D., Kebuladze, N., Tvaradze, A., Colvin, I. 2011: 'Nokalakevi I: ormkhrivprotomiani dzoomorpuli pigurebis kultura' Moambe 2 (47-B): 116-314

— 2013: 'Nokalakevi in the 8th-7th cc BC (the 1st period of development)' Iberia-Kolkheti 9: 212-23

Lomitashvili, D., Lortkipanidze, B., Kapanadze, T., Zamtaradze, M. 2014: 'Previous archaeological work at Nokalakevi, 1973-1998' in P. Everill (ed.), Nokalakevi - Tsikhegoji - Archaeopolis: Archaeological Excavations 2001-2010: Anglo-Georgian Expedition to Nokalakevi. Oxford, Archaeopress: 13-18. https://doi.org/10.30861/9781407312439

Lomitashvili, D., Lortkipanidze, B., Murgulia, N. 2018: 'Akhali monatsemebi nokalaqevis ormotsmocameta eklesiis shesakheb' Moambe 8 (53-B): 139-57

Lordkipanidze, O.D. 1966: Antikuri samyaro da dzveli kolxeti. Tbilisi, Tbilisis Universitetis Gamomcemloba

Lortkipanidze, O. 1995: 'Vani: ein antikes religiöses Zentrum im Lande des Goldenen Vlieses (Kolchis)' Jahrbuch des Römisch-Germanischen Zentralmuseums Mainz 42.2: 353-401

Martin, R.E., Yanko-Hombach, V. 2011: 'Rapid Holocene sea-level and climate change in the Black Sea: an evaluation of the Balabanov sea-level curve' in I.V. Buynevich, V. Yanko-Hombach, A.S. Gilbert, R.E. Martin (eds), Geology and Geoarchaeology of the Black Sea Region: Beyond the Flood Hypothesis. Boulder, Geological Society of America: 51-58. https://doi.org/10.1130/2011.2473(04)

McArthur, J.M., Howarth, R.J., Bailey, T.R. 2001: 'Strontium isotope stratigraphy: LOWESS version 3: best fit to the marine Sr-isotope curve for 0-509 Ma and accompanying look-up table for deriving numerical age' Journal of Geology 109.2: 155-70. https://doi.org/10.1086/319243

McArthur, J.M., Howarth, R.J., Shields, G.A. 2012: 'Strontium isotope stratigraphy' in F.M. Gradstein, J.G. Ogg, M.D. Schmitz, G.M. Ogg (eds), A Geologic Time Scale 2012. Oxford, Elsevier: 127-44. https://doi.org/10.1016/b978-0444-59425-9.00007-x

Meeker, M.E. 1971: 'The Black Sea Turks: some aspects of their ethnic and cultural background' International Journal of Middle East Studies 2.4: 318-45. https://doi.org/10.1017/s002074380000129x

Petersen, A. 2013: 'The archaeology of death and burial in the Islamic world' in L. Nilsson Stutz, S. Tarlow (eds), The Oxford Handbook of the Archaeology of Death and Burial. Oxford, Oxford University Press: 241-58. https://doi.org/10.1093/oxfordhb/9780199569069.013.0014

Reimer, P.J., Bard, E., Bayliss, A., Beck, J.W., Blackwell, P.G., Bronk Ramsey, C., Grootes, P.M., Guilderson, T.P., Haflidason, H., Hajdas, I., Hattž, C., Heaton, T.J., Hoffmann, D.L., Hogg, A.G., Hughen, K.A., Kaiser, K.F., Kromer, B., Manning, S.W., Niu, M., Reimer, R.W., Richards, D.A., Scott, E.M., Southon, J.R., Staff, R.A., Turney, C.S.M., van der Plicht, J. 2013: 'Intcal13 and Marine13 radiocarbon age calibration curves 0-50,000 years cal BP' Radiocarbon 55.4: 1869-87. https://doi.org/10.2458/azu_js_rc.55.16947

Schneider, A.-M. 1931: 'Archaeopolis (Nokalakewi)' Forschungen und Fortschritte 27: 354-55

Shingiray, I. 2018: An Islamicate body: a case study of a nomadic burial from the core territory of the Golden Horde' Revue des mondes musulmans et de la Méditerranée 143: 83-106. https://doi.org/10.4000/remmm.10777

Tielidze, L. (ed.) 2019: Geomorphology of Georgia (Geography of the Physical Environment). Cham, Springer. https://doi.org/10.1007/978-3-319-77764-1

Tielidze, L., Gobejishvili, R., Maruashvili, L., Chikhradze, N. 2019: 'Western Georgia (Kolkheti) intermountain plain' in L. Tielidze (ed.), Geomorphology of Georgia (Geography of the Physical Environment). Cham, Springer: 189204. https://doi.org/10.1007/978-3-319-77764-1_11

Yanko-Hombach, V. 2007: 'Controversy over Noah's flood in the Black Sea: geological and foraminiferal evidence from the shelf' in V. Yanko-Hombach, A.S. Gilbert, N. Panin, P. Dolukanov (eds), The Black Sea Flood Question: Changes in Coastline, Climate, and Human Settlement. Dordrecht, Springer: 149-203. https://doi.org/10.1007/9781-4020-5302-3_7

Zakaraia, P. (ed.) 1981: Nokalakevi-Arkeopolisi: arkeologiuri gatxrebi 1: 1973-1977. Tbilisi, Metsniereba

- (ed.) 1987: Nokalakevi-Arkeopolisi: arkeologiuri gatxrebi 2: 1978-1982. Tbilisi, Metsniereba

- (ed.) 1993: Nokalakevi-Arkeopolisi: arkeologiuri gatxrebi 3: 1983-1989. Tbilisi, Metsniereba 